Article

\title{
Snapshot of Macroalgae and Fish Assemblages in Temperate Reefs in the Southern European Atlantic Ecoregion
}

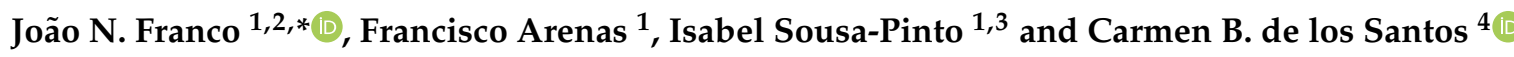 \\ 1 CIIMAR/CIMAR - Interdisciplinary Centre of Marine and Environmental Research, University of Porto, \\ 4450-208 Matosinhos, Portugal; farenas@ciimar.up.pt (F.A.); ispinto@fc.up.pt (I.S.P.) \\ 2 MARE-Marine and Environmental Sciences Centre, ESTM, Instituto Politécnico de Leiria, 2520-620 Peniche, \\ Portugal \\ 3 FCUP-Faculty of Sciences, Department of Biology, University of Porto, 4150-179 Porto, Portugal \\ 4 CCMAR-Center of Marine Sciences of Algarve, University of Algarve, 8005-139 Faro, Portugal; \\ cbsantos@ualg.pt \\ * Correspondence: joaonunofranco@gmail.com
}

Received: 14 November 2019; Accepted: 6 January 2020; Published: 10 January 2020

\begin{abstract}
Most of the biodiversity studies in the South European Atlantic Shelf ecoregion are limited to shallow subtidal or intertidal habitats, while deeper reef habitats, also of relevant ecological importance, are particularly understudied. Macroalgal communities, associated fauna, and sea surface temperature were studied in deep reefs $(25-30 \mathrm{~m})$ at two locations in this ecoregion: Parcel, North of Portugal $\left(41^{\circ} \mathrm{N}\right)$, and Tarifa, Southern Spain $\left(35^{\circ} \mathrm{N}\right)$. Specifically, algal assemblages were assessed using biomass collection and associated ichthyofauna was assessed using visual census techniques using scuba. Seawater surface temperature was higher $\left(>3^{\circ} \mathrm{C}\right)$ in the southern region-Tarifa, compared to the northern region-Parcel. Our survey revealed 18 fish species and 23 algae species. The highest abundance of cold-water species (both macroalgae and fish species) was recorded in Parcel and warm-water species were dominant in Tarifa. In light of climate global trends, both regions might experience biodiversity shifts towards tropicalization. Current knowledge on their biodiversity is imperative to further evaluate potential shifts.
\end{abstract}

Keywords: fauna; flora; marine ecoregions; diversity; Iberian Peninsula; seaweeds; ichthyofauna; algae

\section{Introduction}

The Atlantic waters along the coast of the Iberian Peninsula (across $\sim 7^{\circ}$ of latitude, $36-43^{\circ} \mathrm{N}$, Figure 1) have overlapping biotopes where species of both boreal and Lusitanian origins coexist [1,2] and are included within the same ecoregion, the South European Atlantic Shelf [3]. This temperate marine ecoregion encompasses the Atlantic Iberian Peninsula, which at its southern limit edges with Sahara upwelling off the west coast of Africa and the Alboran Sea, within the Mediterranean [3]. This geographical location also presents a great diversity of oceanographic processes that provide multiple climatic conditions and greatly influence its fauna and flora biodiversity. However, little is known about the biodiversity in this region, which hampers understanding of conservation needs and suggests that developing baseline records should be a research priority. Features that affect macroalgal distribution in the nearshore rocky subtidal zone include wave action, rock slope, stratification of the water column (i.e., temperature, nutrients), sedimentation, biological interactions (grazing, competition), and, most importantly, light $[4,5]$. 


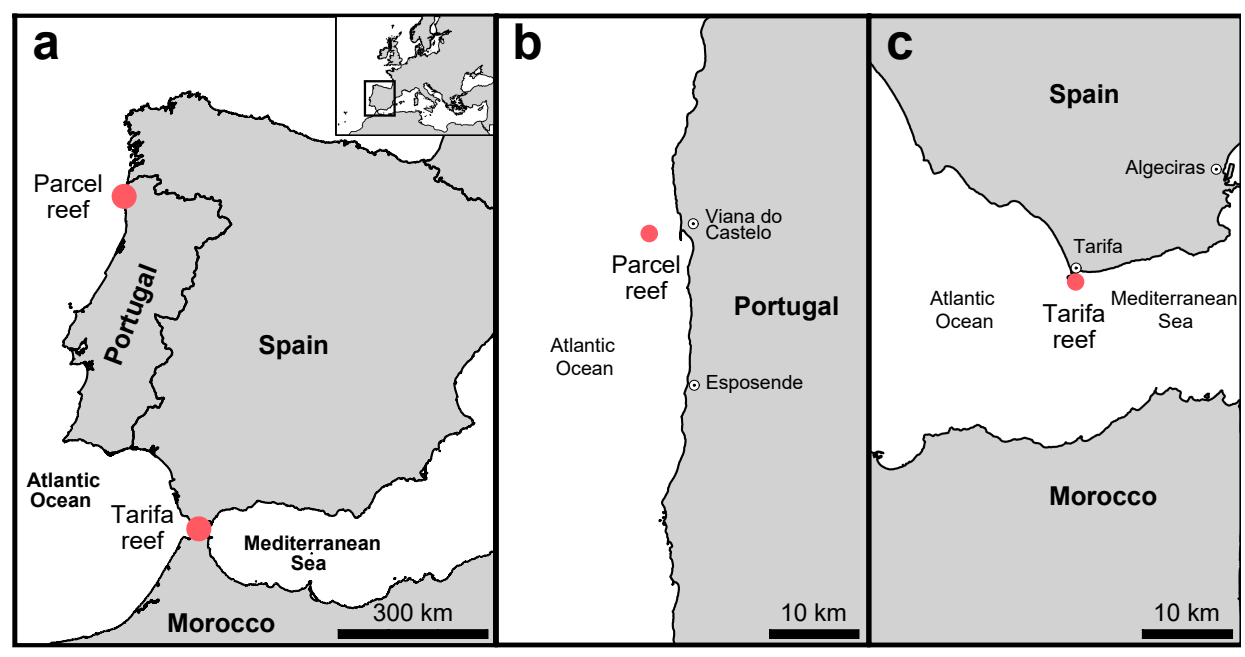

Figure 1. Sampling locations of temperate reefs in the South European Atlantic Shelf marine ecoregion in Iberian Peninsula Atlantic coastal waters (a), showing details of the sampling location in Parcel (b) in Northern Portugal (off Viana do Castelo) and in Tarifa (c) in Southern Spain (Strait of Gibraltar).

Community assemblages in temperate regions are under the threat of climate-driven changes, eventually having profound consequences for their structure and the ecosystem functions they provide [6,7]. In particular, global warming may cause community phase shifts in macroalgal-dominated temperate reefs due to the tropicalization of the community, that is, the intrusion of tropical herbivorous fishes into temperate systems [8,9]. Baseline assessment of the macroalgae and fish assemblages in temperate reefs are therefore necessary to detect potential community shifts due to global warming in the future.

This study aims to characterize macroalgae and fish assemblages of temperate reefs (25-30 m) dominated by macroalgae at two southern Europe locations, Parcel and Tarifa (Figure 1). Both locations belong to the South European Atlantic Shelf ecoregion. Tarifa, situated in the Strait of Gibraltar, is considered a geographical pivotal point located at the junction of two other adjacent ecoregions [3]: the Sahara upwelling (off the west coast of Africa) and the Alboran Sea, within the Mediterranean Sea. Parcel is embedded in the South European Atlantic Shelf away from other adjacent ecoregions. Nevertheless, both locations might experience tropicalization phenomena and therefore biodiversity records are imperative to further understand shifts that potentially can occur.

\section{Materials and Methods}

\subsection{Study Locations and Abiotic Characterization}

Two temperate reefs dominated by kelp forests were included in the study, Parcel and Tarifa (Figure 1). Parcel reef is located in Northern Portugal $\left(41.3^{\circ} \mathrm{N}\right), \approx 2.5$ nautical miles off Viana do Castelo (Figure $1 \mathrm{~b}$ ), and it is found between 26 and $30 \mathrm{~m}$. Tarifa reef is located in the Strait of Gibraltar, south of Spain $\left(36^{\circ} \mathrm{N}\right), \approx 0.5$ nautical mile off the Tarifa coast (Figure 1c) and at the same depth range. The Tarifa reef is characterized by strong tidal currents with peaks of $2.5 \mathrm{~m} \mathrm{~s}^{-1}$ and linked to the presence of upwelling zones [10]. In order to characterize the thermal gradient between both locations, sea surface temperature (SST) was analyzed monthly over a period of 10 years (2009-2018) using area averaging temperature, corresponding to those areas in which the surveys were executed. The data were selected from SST detected by the moderate resolution imaging spectroradiometer (MODIS)-Aqua sensor during night time, available on NASA's Giovanni Web [11], and a $t$-test ( $\alpha=0.5$, two-sided) was used to describe SST differences between locations. In addition, seawater temperature $\left({ }^{\circ} \mathrm{C}\right)$, relative light (lux) and water nutrient concentration (nitrate and phosphate) instant measures were taken in situ during the sampling time (see data in Supplementary Materials, Figure S1). The snapshot surveys 
were conducted on 26 July 2015 in Parcel and on 30 September 2015 in Tarifa, using a small vessel adapted for diving operations.

\subsection{Community Data: Ichthyofauna and Algae Survey}

Ichthyofauna (adult and subadult individuals) were counted and identified within each location. Replicated belt transects $(n=6)$ of $100 \mathrm{~m}^{2}(25 \times 4 \mathrm{~m})$, randomly orientated and separated at least by $50 \mathrm{~m}$, were deployed by the same scuba diver. Along each transect, the diver swam at constant speed, annotating the abundance of each fish species. All samples were taken during daylight hours (i.e., 10:00 and 16:00 UTC+00:00) [12-14]. Fishes were identified to species level and classified in two climatic affinity groups: 'cold-water' boreal fishes and 'warm-water' Lusitanian fishes, following their distributional ranges and previous categorizations across the eastern Atlantic $[12,15,16]$. Cold-water species are usually considered to be northerly taxa that extend north to the Norwegian Sea and Icelandic waters, with southern limits of distribution around the British Isles, west of Brittany, or further south to Iberia, usually in low numbers. Warm-water Lusitanian fishes are usually abundant from the Iberian Peninsula, including the Mediterranean Sea, to the British Isles. Species richness (number of species), proportion of species of each climatic group, and percent relative abundance per species (based on mean number of observed individuals) were calculated for each location.

Algal assemblages were assessed using six replicate quadrats $(50 \times 50 \mathrm{~cm}$, tens to hundreds of meters apart) randomly deployed in each location. Sampling design and resolution were similar to previous studies aimed at describing assemblage-level dynamics of macroalgal systems dominated by small subsurface kelps, e.g., [12,17]. Macroalgae sampling was carried out by scuba divers by scraping all seaweed fronds within each quadrat [12,17]. Algae species within each sample were identified to the lowest feasible taxonomic level and weighed (wet weight after removing excess water). Finally, each taxon was allocated to one of three climatic affinity groups: cold-water Atlantic boreal, warm-water Lusitanian, or widely distributed species $[4,18]$. Species richness (number of species), the proportion of species for each climatic group, and percent relative abundance per species (based on mean wet biomass) were calculated for each location.

\section{Results}

\subsection{Sea Surface Temperature}

Satellite data showed significant differences for SST between the two locations for the period 2009-2018 $(\mathrm{t}=-11.534, \mathrm{df}=237.39, p<0.001$, Figure 2). Sea surface temperature in Parcel was $14.9 \pm 1.9^{\circ} \mathrm{C}$ (mean, SD), with a minimum of $11.1^{\circ} \mathrm{C}$ and maximum of $20.4^{\circ} \mathrm{C}$. In Tarifa SST was $18.1 \pm 2.2{ }^{\circ} \mathrm{C}$ (mean, SD) with a minimum of $14.5^{\circ} \mathrm{C}$ and maximum of $23.4^{\circ} \mathrm{C}$.

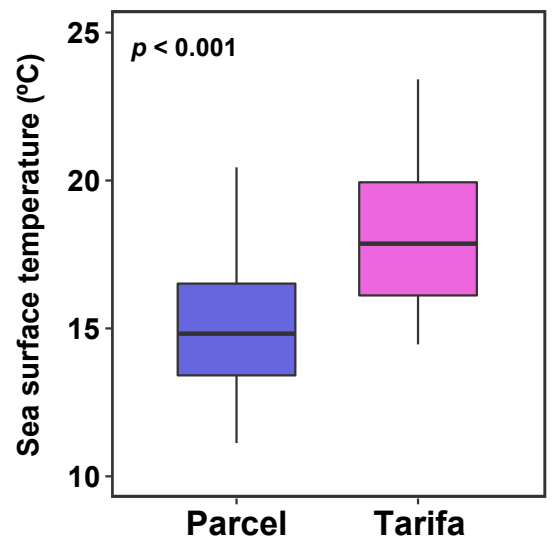

Figure 2. Sea surface temperature at Parcel and Tarifa over a 10-year period (2009-2018). Boxplot bar is the median, box is the interquartile range (IQR), and whiskers are the maximum and minimum values within the $1.5 \times \mathrm{IQR}$ of the hinge $(n=121)$. 


\subsection{Fish and Algae Assemblages}

A total of 18 fish species from eight families were registered in the two locations, with three cold-water boreal species and 16 warm-water Lusitanian species (Table 1). The species richness was higher in Tarifa (14 species) than in Parcel (nine species) (Figure 3a). Labrus bergylta and Trisopterus luscus, both cold-water boreal affinity species were the most abundant fish species in Parcel (29.3 and 22.0\%, respectively), followed by Centrolabrus exoletus ( $21.3 \%$, warm water) and Pollachius pollachius $(16.7 \%$, cold water) (Figure 4). In Tarifa, all but Trisopterus luscus (1.4\%) were warm-water Lusitanian species, with Boops boops and Chromis chromis the most representative species (39.5 and 14.1\%, respectively, Figure 4).

A total of 23 macroalgal species belonging to two phyla (Rhodophyta and Ochrophyta) were identified in Parcel (13 species) and Tarifa (15 species), with five cold-water species, seven warm-water species, and 11 widely distributed species (Table 2). The main contribution to the species richness was from Rhodophyta, with the orders Ceramiales and Gigartinales being particularly rich (five and three species, respectively, Table 2). Ochrophyta were mostly represented by the orders Dictyotales, Laminariales, and Tilopteridales (two species each). When grouped according to their climate affinity, macroalgal assemblages at both Parcel and Tarifa showed a dominance of widely distributed species (53.8 and $46.7 \%$ of total species, respectively, Figure $3 \mathrm{~b}$ ). Parcel showed equal proportion of coldand warm-water taxa $(23.1 \%)$, while Tarifa showed a higher proportion of warm-water taxa $(40.0 \%)$ than cold-water species (13.3\%; Figure 3b). In terms of biomass, kelps were the most representative algae in both locations (Figure 4). In Parcel, kelp species Laminaria hyperborea and Phyllariopsis brevipes accounted for $71 \%$ of total biomass, while Saccorhiza polyschides and Laminaria ochroleuca represented $85.7 \%$ of total biomass in Tarifa (Figure 4). In both locations, the higher relative biomass accounted for cold-water kelp species (Figure 4).

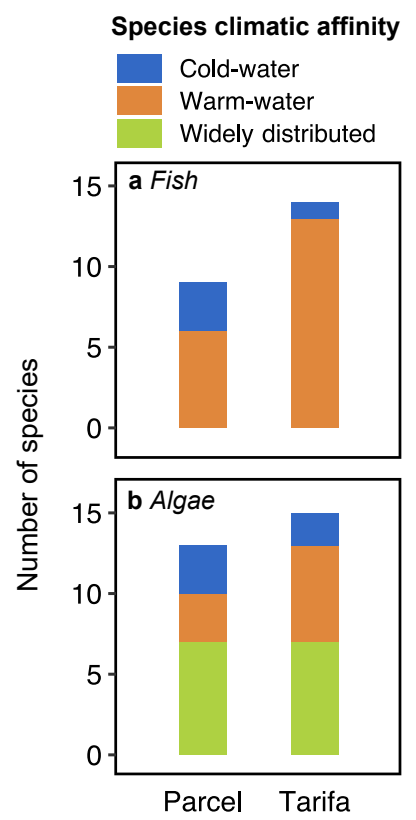

Figure 3. Number of fish (a) and algae (b) species by climatic affinity in Parcel and Tarifa. 


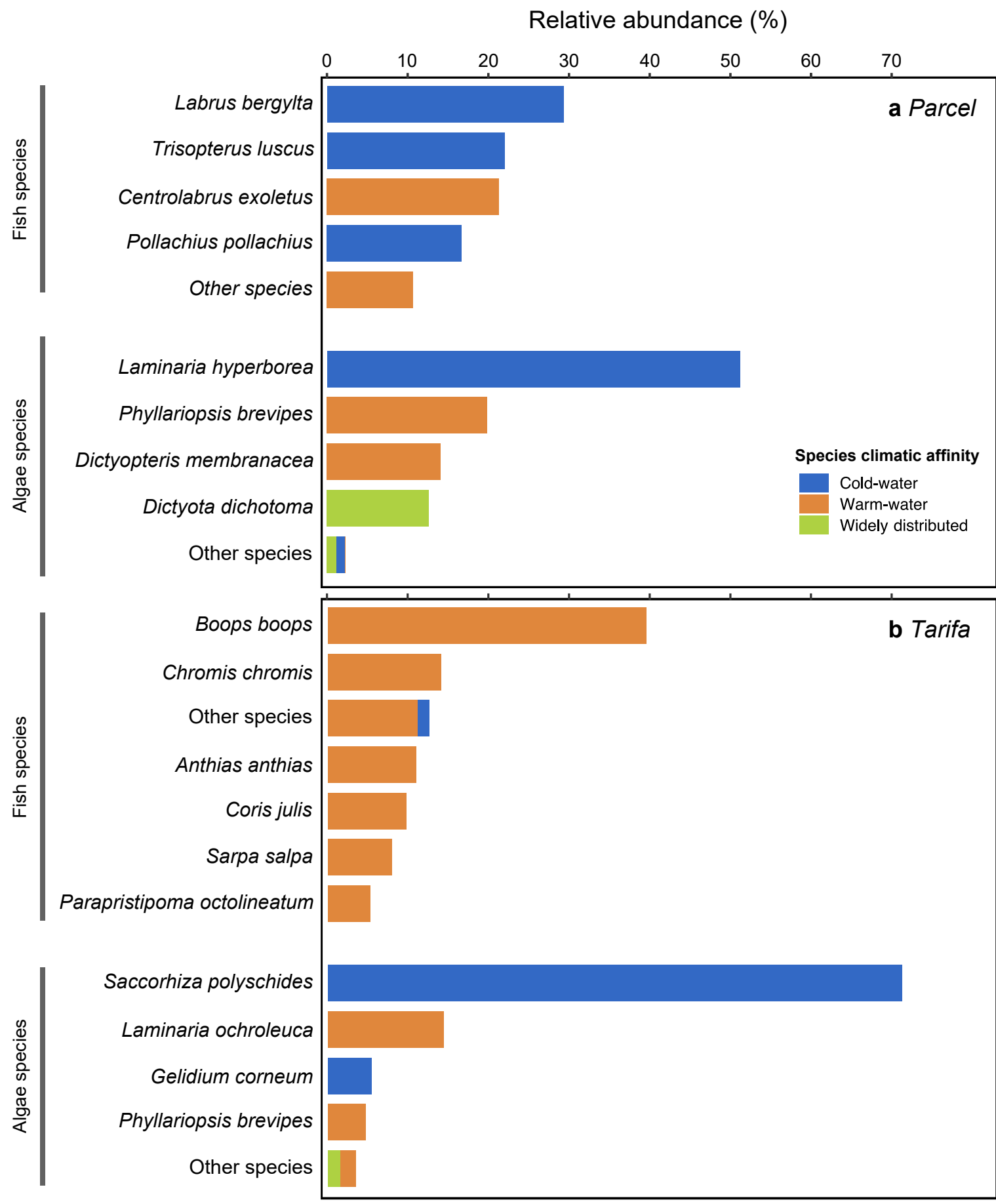

Figure 4. Relative abundance for the main species of fish (based on numbers of individuals) and algae (based on wet biomass) by climatic affinity in Parcel (a) and Tarifa (b). 
Table 1. List of fish species and abundance (individuals per $100 \mathrm{~m}^{2}$, mean $\pm \mathrm{SD}, n=6$ ) identified in Parcel and Tarifa locations, along with their climatic affinity: cold-water boreal (Cd) or warm-water Lusitanian (Wr) species. All taxonomic authorities were verified through cited references in [15] (December 2019).

\begin{tabular}{ccccc}
\hline Family & Species & Climatic Affinity & Parcel & Tarifa \\
\hline Serranidae & Anthias anthias Linnaeus, 1758 & $\mathrm{Wr}$ & & $15.7 \pm 6.0$ \\
Sparidae & Boops boops Linnaeus, 1758 & $\mathrm{Wr}$ & $56.7 \pm 22.5$ \\
Labridae & Coris julis Linnaeus, 1758 & $\mathrm{Wr}$ & $0.5 \pm 1.2$ & $14.0 \pm 8.9$ \\
Pomacentridae & Chromis chromis Linnaeus, 1758 & $\mathrm{Wr}$ & & $20.2 \pm 8.5$ \\
Labridae & Centrolabrus exoletus Linnaeus, 1758 & $\mathrm{Wr}$ & $5.3 \pm 1.8$ & \\
Labridae & Ctenolabrus rupestris Linnaeus, 1758 & $\mathrm{Wr}$ & $0.2 \pm 0.4$ & $2.2 \pm 1.2$ \\
Moronidae & Dicentrarchus labrax Linnaeus, 1758 & $\mathrm{Wr}$ & $1.0 \pm 1.3$ & \\
Sparidae & Diplodus cervinus Lowe, 1838 & $\mathrm{Wr}$ & & $2.5 \pm 0.8$ \\
Sparidae & Diplodus sargus Linnaeus, 1758 & $\mathrm{Wr}$ & & $5.7 \pm 1.6$ \\
Sparidae & Diplodus vulgaris Geoffroy Saint-Hilaire, 1817 & $\mathrm{Wr}$ & $0.3 \pm 0.8$ & $2.7 \pm 2.1$ \\
Labridae & Labrus bergylta Ascanius, 1767 & $\mathrm{Cd}$ & $7.3 \pm 8.1$ & $1.0 \pm 1.3$ \\
Mullidae & Mullus surmuletus Linnaeus, 1758 & $\mathrm{Wr}$ & & $7.5 \pm 4.8$ \\
Haemulidae & Parapristipoma octolineatum Valenciennes, 1833 & $\mathrm{Wr}$ & & \\
Gadidae & Pollachius pollachius Linnaeus, 1758 & $\mathrm{Cd}$ & $4.2 \pm 8.0$ & $11.3 \pm 6.9$ \\
Sparidae & Sarpa salpa Linnaeus, 1758 & $\mathrm{Wr}$ & & $1.0 \pm 0.9$ \\
Serranidae & Serranus cabrilla Linnaeus, 1758 & $\mathrm{Wr}$ & & $1.0 \pm 1.1$ \\
Labridae & Symphodus melops Linnaeus, 1758 & $\mathrm{Wr}$ & $0.7 \pm 1.2$ & $2.0+4.9$ \\
Gadidae & Trisopterus luscus Linnaeus, 1758 & $\mathrm{Cd}$ & $5.5 \pm 7.9$ & 2.9 \\
\hline
\end{tabular}

Table 2. List of algae species identified in Parcel and Tarifa locations, along with their biomass abundance (g wet weight per $0.25 \mathrm{~m}^{2}$, mean $\pm \mathrm{SD}, n=12$ ) and its climatic affinity: cold-water Atlantic-boreal (Cd), warm-water Lusitanian species (Wr), or widely distributed (Wd) species. All taxonomic authorities were verified through cited references in [19] (December 2019).

\begin{tabular}{|c|c|c|c|c|}
\hline Order & Species & $\begin{array}{l}\text { Climatic } \\
\text { Affinity }\end{array}$ & Parcel & Tarifa \\
\hline \multicolumn{5}{|c|}{ Class Phaeophyceae } \\
\hline Dictyotales & $\begin{array}{l}\text { Dictyopteris polypodioides (A.P. De Candolle) J.V. } \\
\text { Lamouroux, } 1809\end{array}$ & Wr & $37.30 \pm 28.28$ & $1.29 \pm 3.17$ \\
\hline \multirow[t]{2}{*}{ Laminariales } & Laminaria hyperborea (Gunnerus) Foslie, 1884 & $\mathrm{Cd}$ & $135.34 \pm 109.27$ & \\
\hline & Lamiraria ochroleuca Bachelot de la Pylaie, 1824 & $\mathrm{Wr}$ & & $191.67 \pm 187.55$ \\
\hline Sphacelariales & Halopteris filicina (Grateloup) Kützing, 1843 & $\mathrm{Wr}$ & & $1.18 \pm 1.86$ \\
\hline Sporochnales & Carpomitra costata (Stackhouse) Batters, 1902 & $\mathrm{Wr}$ & & $1.58 \pm 3.86$ \\
\hline Tilopteridales & $\begin{array}{c}\text { Phyllariopsis brevipes (C. Agardh) E.C. Henry and G.R. } \\
\text { South, } 1897\end{array}$ & $\mathrm{Wr}$ & $52.48 \pm 55.47$ & $62.50 \pm 50.20$ \\
\hline \multirow[t]{2}{*}{ Rhodymeniales } & Rhodymenia holmesii Ardissone, 1893 & Wr & $0.16 \pm 0.28$ & \\
\hline & $\begin{array}{c}\text { Rhodymenia pseudopalmata (J.V. Lamouroux) P.C. Silva, } \\
1952\end{array}$ & $\mathrm{Wd}$ & $0.19 \pm 0.22$ & \\
\hline \multirow[t]{5}{*}{ Ceramiales } & Acrosorium ciliolatum (Harvey) Kylin, 1924 & Wd & $1.59 \pm 1.36$ & \\
\hline & Chondria dasyphylla (Woodward) C. Agardh, 1817 & Wd & $0.34 \pm 0.82$ & \\
\hline & Cryptopleura ramose (Hudson) L. Newton, 1931 & Wd & $0.30 \pm 0.47$ & \\
\hline & $\begin{array}{c}\text { Hypoglossum hypoglossoides (Stackhouse) Collins and } \\
\text { Hervey, } 1917\end{array}$ & $\mathrm{Wd}$ & $0.10 \pm 0.00$ & $0.70 \pm 0.05$ \\
\hline & Pterothamnion plumula (J. Ellis) Nägeli, 1855 & $\mathrm{Cd}$ & $0.02 \pm 0.05$ & \\
\hline Gelidiales & Peyssonnelia coriacea Feldmann, 1941 & Wd & & $3.01 \pm 7.37$ \\
\hline Gigartinales & Gelidium corneum (Hudson) J.V. Lamouroux, 1813 & $\mathrm{Cd}$ & & $71.97 \pm 97.31$ \\
\hline
\end{tabular}




\section{Discussion}

Our snapshot study at the temperate reefs (25-30 m) of Parcel and Tarifa coastal waters have revealed records of 23 macroalgal species and 18 fish taxa. Parcel and Tarifa are within the same marine ecoregion, the South European Atlantic Shelf, but with nonhomogeneous ocean climate and potential biodiversity differences [7]. For example, previous studies have registered a similar seawater temperature gradient of $1-3{ }^{\circ} \mathrm{C}$ across the Viana Castelo and Gibraltar Strait regions [12,20]. Our sampling sites, Parcel (northern location) and Tarifa (southern location) are within those regions and have revealed on average a similar thermal gradient during the analyzed 10-year period, with warmer water in Tarifa than in Parcel $\left(3.2^{\circ} \mathrm{C}\right.$ difference). The thermal affinity was reflected in terms of fish abundance, with a high proportion of warm-water fish species in Tarifa and of cold-water fish species in Parcel. The highest biomass recorded in Parcel was for the kelp Laminaria hyperborea, a cold-water species, while in Tarifa the highest biomass value was recorded for the cold-water kelp Saccorhiza polyschides and secondly for the warm-water kelp species, Laminaria ochroleuca. Not surprisingly, our results demonstrated higher abundance of cold-water species in Parcel while warm-water species are dominant in Tarifa, in accordance with the registered abiotic conditions. Nevertheless, the high representativeness of a cold-water species at the Tarifa deeper reefs may suggest favorable climatic conditions at least at the studied depth range $(25-30 \mathrm{~m})$ where $S$. polyschides could benefit from the colder waters from the bottom and avoid thermal floatations more frequently and intensely at the very shallow or intertidal areas near the same location.

Ocean climate patterns, e.g., seawater temperature, primary productivity, upwelling regimen [2,12,21,22] and/or biologic interactions, e.g., herbivory [13,23] (Figure S2) are amongst the factors contributing to the biodiversity distribution patterns. This study represents only a snapshot of the biodiversity at these locations and the recorded species list should not be considered comprehensive. Nevertheless, this study may represent a valuable baseline for future studies in Tarifa and Parcel reefs regarding species distributional shifting or tropicalization. Indeed, episodes of tropicalization of temperate waters where cold-water species retreating poleward concomitantly with the advance of tropical or subtropical affinity species are becoming more frequent $[24,25]$, along and within the studied regions [26-29]. Biodiversity records in these regions are usually limited to intertidal or subtidal levels up to $15 \mathrm{~m}[12,30,31]$ and studies at deeper depths are scarce. Deep-water environments can play an important role as refugia [32] and are logistically difficult to study, therefore more efforts are needed to further increase quantitative and qualitative biodiversity data, including different spatial and time scales.

Supplementary Materials: The following are available online at http://www.mdpi.com/1424-2818/12/1/26/s1, Figure S1: In situ measurements of abiotic data of Parcel and Tarifa, Figure S2: Herbivory marks on algae.

Author Contributions: Conceptualization, J.N.F.; data curation, F.A. and C.B.d.1.S.; formal analysis, J.N.F. and C.B.d.1.S.; funding acquisition, J.N.F., I.S.-P. and C.B.d.1.S.; investigation, J.N.F., I.S.-P. and C.B.d.1.S.; methodology, J.N.F. and F.A.; validation, C.B.d.l.S.; visualization, J.N.F., F.A., I.S.-P. and C.B.d.l.S.; writing-original draft, J.N.F.; writing-review and editing, J.N.F., F.rancisco Arenas, I.S.-P. and C.B.d.1.S.. All authors have read and agreed to the published version of the manuscript.

Funding: João N. Franco and Carmen B. de los Santos were supported by the Portuguese national funds from FCT-Foundation for Science and Technology through fellowships SFRH/BD/84933/2012 and SFRH/BPD/119344/2016, respectively. Additional funding was provided from the project SEEINGSHORE (NORTE-01-0145-FEDER-031893), co-financed by NORTE 2020, Portugal 2020 and the European Union through the ERDF, and by FCT through national funds. This study also received Portuguese national funds from FCT through the project UID/Multi/04326/2019.

Acknowledgments: We would like to thanks to Cavaleiros do Mar and YellowSub Tarifa diving centers for logistic support. We acknowledge the MODIS mission scientists and associated NASA personnel for the production of the satellite data used in this research effort. We also acknowledge F. Tuya, T. Wernberg and B. Martínez for underwater field assistance in Parcel and anonymous reviewers for their suggestions.

Conflicts of Interest: The authors declare no conflict of interest. 


\section{References}

1. Southward, A.J.; Hawkins, S.J.; Burrows, M.T. Seventy years' observations of changes in distribution and abundance of zooplankton and intertidal organisms in the western English Channel in relation to rising sea temperature. J. Therm. Biol. 1995, 20, 127-155. [CrossRef]

2. Lima, F.P.; Ribeiro, P.A.; Queiroz, N.; Hawkins, S.J.; Santos, A.M. Do distributional shifts of northern and southern species of algae match the warming pattern? Glob. Chang. Biol. 2007, 13, 2592-2604. [CrossRef]

3. Spalding, M.D.; Fox, H.E.; Allen, G.R.; Davidson, N.; Ferdaña, Z.A.; FINLAYSON, M.; Halpern, B.S.; Jorge, M.A.; Lombana, A.; Lourie, S.A.; et al. Marine Ecoregions of the World: A Bioregionalization of Coastal and Shelf Areas. Bioscience 2007, 57, 573. [CrossRef]

4. Lüning, K. Seaweeds: Their Environment, Biogeography and Ecophysiology, by Klaus Lünin; John Wiley: New York, NY, USA, 1990; ISBN 978-0-471-62434-9.

5. Wiencke, C.; Bischof, K. (Eds.) Seaweed Biology; Ecological Studies; Springer: Berlin/Heidelberg, Germany, 2012; Volume 219, ISBN 978-3-642-28450-2.

6. Zarnetske, P.L.; Skelly, D.K.; Urban, M.C. Biotic multipliers of climate change. Science 2012, 336, $1516-1518$. [CrossRef]

7. Vergés, A.; McCosker, E.; Mayer-Pinto, M.; Coleman, M.A.; Wernberg, T.; Ainsworth, T.; Steinberg, P.D. Tropicalisation of temperate reefs: Implications for ecosystem functions and management actions. Funct. Ecol. 2019, 33, 1000-1013. [CrossRef]

8. Poloczanska, E.S.; Brown, C.J.; Sydeman, W.J.; Kiessling, W.; Schoeman, D.S.; Moore, P.J.; Brander, K.; Bruno, J.F.; Buckley, L.B.; Burrows, M.T.; et al. Global imprint of climate change on marine life. Nat. Clim. Chang. 2013, 3, 919-925. [CrossRef]

9. Last, P.R.; White, W.T.; Gledhill, D.C.; Hobday, A.J.; Brown, R.; Edgar, G.J.; Pecl, G. Long-term shifts in abundance and distribution of a temperate fish fauna: A response to climate change and fishing practices. Glob. Ecol. Biogeogr. 2011, 20, 58-72. [CrossRef]

10. Flores-Moya, A. Warm Temperate Seaweed Communities: A Case Study of Deep Water Kelp Forests from the Alboran Sea (SW Mediterranean Sea) and the Strait of Gibraltar. In Seaweed Biology; Wiencke, C., Bischof, K., Eds.; Springer: Berlin/Heidelberg, Germany, 2012; Volume 219, pp. 471-493. ISBN 978-3-642-28450-2.

11. Acker, J.G.; Leptoukh, G. Online analysis enhances use of NASA Earth Science Data. Eos (Washington. DC.) 2007, 88. Available online: https://agupubs.onlinelibrary.wiley.com/doi/pdf/10.1029/2007EO020003 (accessed on 20 December 2019). [CrossRef]

12. Tuya, F.; Cacabelos, E.; Duarte, P.; Jacinto, D.; Castro, J.; Silva, T.; Bertocci, I.; Franco, J.; Arenas, F.; Coca, J.; et al. Patterns of landscape and assemblage structure along a latitudinal gradient in ocean climate. Mar. Ecol. Prog. Ser. 2012, 466, 9-19. [CrossRef]

13. Franco, J.N.; Wernberg, T.; Bertocci, I.; Duarte, P.; Jacinto, D.; Vasco-Rodrigues, N.; Tuya, F. Herbivory drives kelp recruits into "hiding" in a warm ocean climate. Mar. Ecol. Prog. Ser. 2015, 536, 1-9. [CrossRef]

14. Tuya, F.; Wernberg, T.; Thomsen, M.S. The relative influence of local to regional drivers of variation in reef fishes. J. Fish Biol. 2011, 79, 217-234. [CrossRef] [PubMed]

15. Froese, R.; Pauly, D. FishBase. Available online: www.fishbase.org (accessed on 20 December 2019).

16. Wheeler, A.C.; Merrett, N.R.; Quigley, D.T.G. Additional records and notes for Wheeler's (1992) List of the Common and Scientific Names of Fishes of the British Isles. J. Fish Biol. 2004, 65, 1-40.

17. Wernberg, T.; Kendrick, G.A.; Phillips, J.C. Regional differences in kelp-associated algal assemblages on temperate limestone reefs in south-western Australia. Divers. Distrib. 2003, 9, 427-441. [CrossRef]

18. Alvarez, M.; Gallardo, T.; Ribera, M.A.; Garreta, A.G. A reassessment of Northern Atlantic seaweed biogeography. Phycologia 1988, 27, 221-223. [CrossRef]

19. Guiry, M.D.; Guiry, G.M. AlgaeBase. Available online: www.algaebase.org (accessed on 20 December 2019).

20. García-Sánchez, M.J.; Delgado-Huertas, A.; Fernández, J.A.; Flores-Moya, A. Photosynthetic use of inorganic carbon in deep-water kelps from the Strait of Gibraltar. Photosynth. Res. 2016, 127, 295-305. [CrossRef]

21. Lemos, R.T.; Pires, H.O. The upwelling regime off the west Portuguese coast, 1941-2000. Int. J. Climatol. 2004, 24, 511-524. [CrossRef]

22. Franco, J.N.; Tuya, F.; Bertocci, I.; Rodríguez, L.; Martínez, B.; Sousa-Pinto, I.; Arenas, F. The 'golden kelp' Laminaria ochroleuca under global change: Integrating multiple eco-physiological responses with species distribution models. J. Ecol. 2018, 106, 47-58. [CrossRef] 
23. Franco, J.N.; Wernberg, T.; Bertocci, I.; Jacinto, D.; Maranhão, P.; Pereira, T.; Martinez, B.; Arenas, F.; Sousa-Pinto, I.; Tuya, F. Modulation of different kelp life stages by herbivory: Compensatory growth versus population decimation. Mar. Biol. 2017, 164, 164. [CrossRef]

24. Vergés, A.; Steinberg, P.D.; Hay, M.E.; Poore, A.G.B.; Campbell, A.H.; Ballesteros, E.; Heck, K.L.; Booth, D.J.; Coleman, M.A.; Feary, D.A.; et al. The tropicalization of temperate marine ecosystems: Climate-mediated changes in herbivory and community phase shifts. Proc. R. Soc. B Biol. Sci. 2014, 281, 20140846. [CrossRef]

25. Wernberg, T.; Bennett, S.; Babcock, R.C.; de Bettignies, T.; Cure, K.; Depczynski, M.; Dufois, F.; Fromont, J.; Fulton, C.J.; Hovey, R.K.; et al. Climate-driven regime shift of a temperate marine ecosystem. Science 2016, 353, 169-172. [CrossRef]

26. Raitsos, D.E.; Beaugrand, G.; Georgopoulos, D.; Zenetos, A.; Pancucci-Papadopoulou, A.M.; Theocharis, A.; Papathanassiou, E. Global climate change amplifies the entry of tropical species into the eastern Mediterranean Sea. Limnol. Oceanogr. 2010, 55, 1478-1484. [CrossRef]

27. Bañón, R.; Fernández, A.; Arronte, J.C.; García, D.; Villamarín, A. New records of two southern fishes found in northern waters of the Iberian Peninsula. Acta Ichthyol. Piscat. 2017, 47, 401-405. [CrossRef]

28. Horta E Costa, B.; Assis, J.; Franco, G.; Erzini, K.; Henriques, M.; Gonçalves, E.J.; Caselle, J.E. Tropicalization of fish assemblages in temperate biogeographic transition zones. Mar. Ecol. Prog. Ser. 2014, 504, 241-252. [CrossRef]

29. Encarnação, J.; Morais, P.; Baptista, V.; Cruz, J.; Teodósio, M.A. New evidence of marine fauna tropicalization offthe Southwestern Iberian Peninsula (Southwest Europe). Diversity 2019, 11, 1-11. [CrossRef]

30. Araújo, R.; Sousa-Pinto, I.; Bárbara, I.; Quintino, V. Macroalgal communities of intertidal rock pools in the northwest coast of Portugal. Acta Oecologica 2006, 30, 192-202. [CrossRef]

31. Hernández, I.; Bermejo, R.; Vergara, J.J.; Olivé, I.; Fernando, G.; Mourente, G.; de los Santos, C.B.; Pérez-lloréns, J.L. Estudio ficológico del intermareal y fondos submareales del sector oriental del Parque Natural del Estrecho, entre el puerto de Tarifa y Piedra Alta. MIGRES Rev. Ecol. 2011, 2, 1-10.

32. Assis, J.; Coelho, N.C.; Lamy, T.; Valero, M.; Alberto, F.; Serrão, E.Á. Deep reefs are climatic refugia for genetic diversity of marine forests. J. Biogeogr. 2016, 43, 833-844. [CrossRef] 